\title{
Insulin resistance syndrome: possible key role of blood flow in resting muscle
}

\author{
P.O.Ganrot \\ Department of Clinical Chemistry, Örebro Medical Center Hospital, Örebro, Sweden
}

Since the greater part of insulin-mediated glucose disposal occurs in muscle any reduction of muscle uptake has been perceived as "insulin resistance" (IR). In most cases, however, the mechanism is unexplained and the supposed connection with insulin must be seriously questioned. By definition, insulin is the normal rate-limiting factor for insulin-dependent glucose uptake. IR indicates that some other factor - not necessarily related to insulin - tends to take over this role. Although this new restricting factor is not well known in common IR, most likely it is to be found among the factors which set an upper limit for glucose uptake, when insulin is raised beyond physiological levels. The presence of such latent limiting factors in normal subjects is illustrated by the hyperinsulinaemic euglycaemic clamp curve. As soon as insulin begins to exceed the physiological range the curve begins to level off, indicating that glucose uptake has encountered some other limiting factor. Muscle blood flow may well be this factor [1].

The present discussion is an attempt to show how reduced blood flow in resting muscle may have a key role in the development of common IR. It may not only restrict glucose delivery to muscles and cause impaired glucose tolerance and Type 2 (non-insulin-dependent) diabetes mellitus but may also explain, or be explained by, fundamental features of the other disorders of the proposed insulin resistance syndrome [2-4].

\section{Muscle blood flow and insulin-dependent glucose uptake in normal subjects}

The hyperinsulinaemic euglycaemic insulin clamp has become something of an operational definition for IR. The metabolic conditions it imposes are therefore of special interest. For kinetic reasons, blood flow in muscles must be rate-limiting for their glucose uptake if a high insulin level is combined with a normal glucose level [5]. Glucose extraction of $20-30 \%$ across the leg or forearm has been reported [6,7], but part of the venous blood came from tissues with low uptake. Therefore, we can assume that muscle uptake may have been as high as $40 \%$. With arterial blood glucose clamped at $5 \mathrm{mmol} / \mathrm{l}$, venous blood leaving muscles would then contain $3 \mathrm{mmol} / \mathrm{l}$. The interstitial fluid level would also be $3 \mathrm{mmol} / 1$, or lower if equilibrium is not attained across the capillary wall. This level is crucial for the uptake, since the insulin-dependent glucose transporter has an apparent $\mathrm{K}_{\mathrm{m}}$ of about $6-8 \mathrm{mmol} / 1[8,9]$. It therefore operates within the range where transport rate is directly dependent on the concentration. A lower rate of blood flow would cause a fall in delivery of glucose and a lower interstitial fluid level and thus a corresponding fall in the cell uptake rate [5]. That blood flow has this effect has been demonstrated in animals [10-12].

Another indication for glucose delivery being ratelimiting for cell uptake in the hyperinsulinaemic state comes from a more complex kinetic study in normal young male subjects [8]. Glucose disposal was studied at varying insulin ( 9 to $1700 \mathrm{mU} / \mathrm{l}$ ) and glucose (5 to $22 \mathrm{mmol} / \mathrm{l}$ ) levels. $K_{\mathrm{m}}$-values were found to increase from $7-8 \mathrm{mmol} / \mathrm{l}$ for the lowest insulin level to about $30 \mathrm{mmol} / \mathrm{l}$ for the highest. The authors considered the increase to be apparent and caused by a shift in the rate-limiting step from cell membrane transport to "some step beyond". Although this step was not specified, the implication that it may be some of the enzymatic steps on the pathway to glycogen must be questioned. Assuming the insulin-dependent glucose transporter to be the only rate-limiting factor, MichaelisMenten curves with identical $\mathrm{K}_{\mathrm{m}}$-values would be obtained for all insulin levels. If a high uptake rate would lead to some enzymatic step becoming overloaded, metabolites would accumulate backwards from the new ratelimiting step and prevent further increase of uptake. $V_{\max }$ for disposal at the highest glucose level would be suppressed, but glucose disposal at lower levels would be less influenced. This would cause an apparent reduction of the $\mathrm{K}_{\mathrm{m}}$-value (Fig. 1). If, on the other hand, high insulin-mediated cell uptake capacity would lead to glucose delivery becoming critical, it would affect the actual uptake most strongly at low blood glucose levels. The first part of the curve would then be suppressed more than $V_{\max }$, leading to an apparent increase in $\mathrm{K}_{\mathrm{m}}$, in agreement with reported data. Therefore, even if the authors may have come to a 


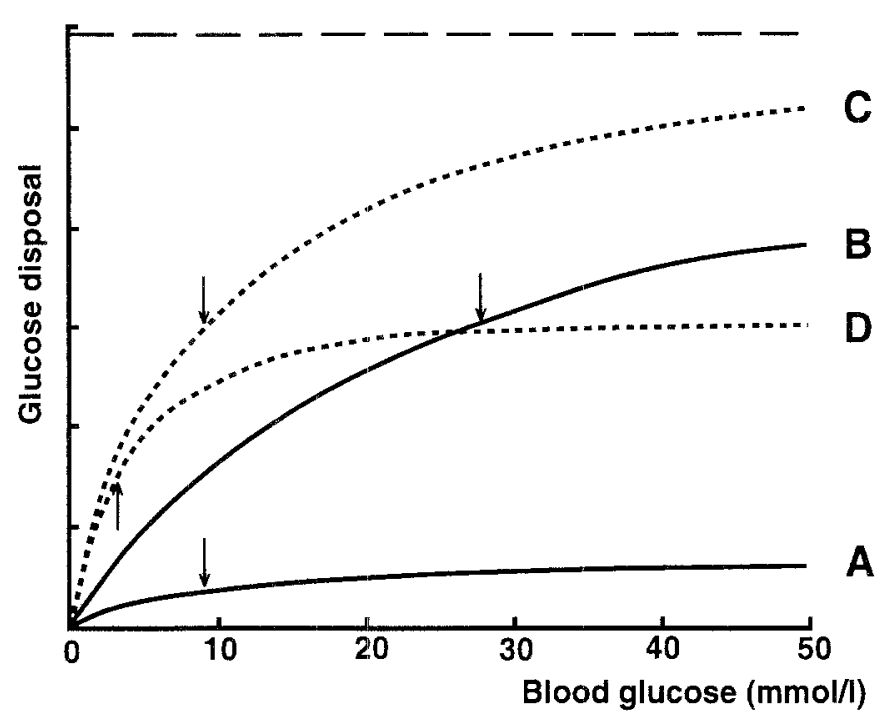

Fig.1. Distortion of glucose disposal kinetics by a rate-limiting step before and after the cell membrane transport. A and B: Reported glucose uptake at basal and maximal $(1700 \mathrm{mU} / \mathrm{l})$ insulin levels [8]. C: Expected curve with $\mathrm{K}_{\mathrm{m}}(\downarrow)$ of curve $A$ and $\mathrm{V}_{\max }(---)$ ) of curve B. D: Uptake with transport capacity as in C but with an intracellular rate-limiting step. Arrows indicate $\mathrm{K}_{\mathrm{m}}$ for the respective curve

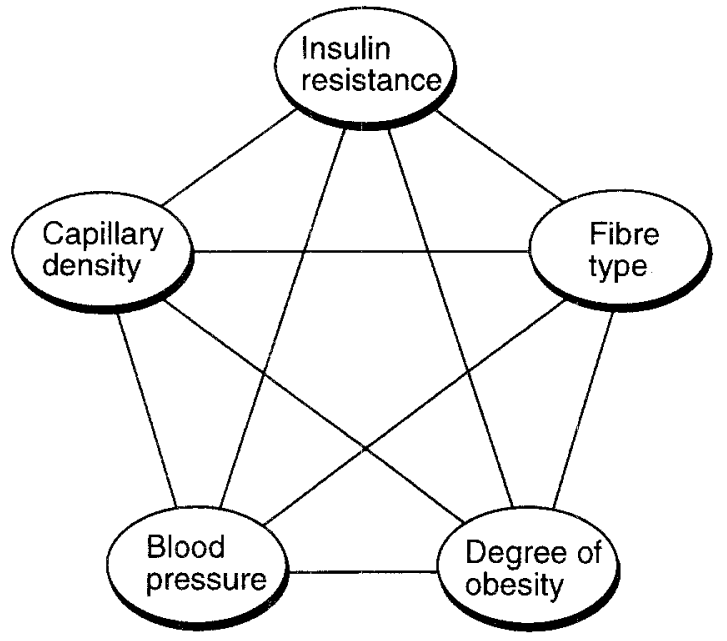

Fig. 2. Reported correlations (positive and negative) between some physiological variables

different conclusion, the report seems to indicate that the new rate-limiting factor, appearing at high insulin levels, is positioned prior to the glucose transporter. Blood flow and capillary diffusion are then the only candidates.

A third indication that blood flow in resting muscle is rate-limiting for insulin-dependent glucose disposal may be found in studies on the effect of muscle exercise. Exercise has a well-known, beneficial effect on the metabolic control in Type 2 diabetes and is also a powerful stimulator of insulin-dependent glucose uptake in normal subjects. That blood flow is the limiting factor is indicated by a study combining insulin clamp with bicycle exercise and measurement of blood flow and glucose uptake in the leg [13]. A close correlation was found between glucose uptake and leg blood flow $(r=0.935)$. Similar results were obtained for rat hindlimbs, stimulated electrically to contract [10].

A fourth indication for blood flow being rate-limiting for glucose uptake may be inferred from comparative physiology. The trans-membrane transport capacity of human erythrocytes exceeds the metabolic needs of the cells more than 10,000-fold [14]. An almost instantaneous equilibrium is therefore maintained between the erythrocyte and plasma glucose levels, making intracellular water space also available for transport to the tissues. Primates are reported to be unique in this respect, other mammalian erythrocytes having a high transporter capacity only during fetal life [14]. This may suggest that blood flow is rate-limiting for the delivery of glucose to some important tissue and that it has proved necessary during evolution to utilize the erythrocyte water for the transportation. Humans are also unique in having a very low blood flow rate in resting muscle, about $20 \mathrm{ml} \cdot \mathrm{min}^{-1} \cdot \mathrm{kg}^{-1}$ muscle, most other mammalians having flow rates of $50-100 \mathrm{ml} \cdot \mathrm{min}^{-1}$ $\mathrm{kg} \cdot{ }^{-1}[15]$. Brain and placenta have been proposed as the organs which require additional glucose supply but muscle seems a much more plausible candidate. Most of the glucose taken up by brain and placenta is oxidized and glucose extraction can hardly increase beyond the limit set by oxygen supply. Extractable oxygen of fully saturated blood can at most oxidize glucose corresponding to $1 \mathrm{mmol} / \mathrm{l}$. Glucose storage in muscle requires much less oxygen (theoretically about $6 \%$ ) for the same amount of glucose to be taken up. Therefore, muscle should be able to extract more glucose, but uptake is restricted by the fall in the interstitial glucose level it causes and by the low blood flow rate. Glucose-transporting erythrocytes may help muscle to circumvent this problem.

Blood flow thus influences glucose uptake, but a reverse effect also exists. In normal males, leg blood flow increased from 250 to about $400 \mathrm{ml} / \mathrm{min}$ when basal insulin was raised to about $300 \mathrm{mU} / 1$. A concomitant rise of the glucose level from 5 to $25 \mathrm{mmol} / \mathrm{l}$ further increased leg flood flow to about $650 \mathrm{ml} / \mathrm{min}[9,16]$. This implies that muscle blood flow and glucose uptake are coupled in a system of mutual reinforcement that might serve as a feedback system, adjusting disposal of glucose to the actual influx to the blood. These complex interactions emphasize the role of muscle blood flow in the pathogenesis of IR.

\section{Muscle blood flow in the insulin resistance syndrome}

Few studies have been performed on blood flow of resting muscle in IR and Type 2 diabetes and thus, it is not clear how blood flow may be influenced. Some authors have reported that the flow rate is less sensitive than normal to factors causing vasodilation, e. g. exercise $[17,18]$, glucose uptake (see below) or infusion of acetylcholine and glyceryl trinitrate [19]. The findings are consistent with the hypothesis that in IR the resistance vessels are in a constant state of relative dilation, possibly to compensate for restricting structural changes [17].

Basal leg blood flow in obese subjects did not differ significantly from that in lean subjects but increased much less when insulin and glucose were clamped at high levels 
$[9,16]$. Laakso et al. $[20,21]$ concluded that the difference in blood flow response had contributed significantly to the lower rate of glucose uptake in obese subjects and constituted "a novel mechanism of insulin resistance". Clamp studies were also performed on obese, Type 2 diabetic subjects with even lower insulin sensitivity and responsiveness. Leg blood flow response during the clamp was much lower than in non-diabetic subjects [20, 21]. The authors considered the decreased insulin responsiveness in the Type 2 diabetic group "to be largely due to reduced skeletal muscle blood flow".

Recently, the hypothesis was presented that "haemodynamic factors" are the link between IR and hypertension [22]. The most convincing arguments were compiled from reports on the metabolic effects of antihypertensive agents. Beta-receptor blocking agents and and thiazide drugs decrease cardiac output and blood flow. In addition they have well-known adverse effects, which increase IR and impair glucose tolerance [23-25]. Alpha-adrenergic antagonists and angiotensin-converting-enzyme inhibitors are peripheral vasodilators which increase blood flow and they have an alleviating effect on IR [24, 26, 27]. Calcium channel blockers also decrease vascular resistance, but only weak alleviating effects on IR have been noted [28]. It is remarkable that all major groups of antihypertensive agents affect IR exactly in the way that they would do, if muscle blood flow had a major role in the development of IR. The mechanism is probably via decreased delivery of glucose. The possibility of insulin delivery being the critical factor [29] seems less likely since it could not lead to decreased insulin responsiveness.

The same haemodynamic factors may contribute to IR-related dyslipidaemia. Antihypertensive agents affect plasma triglycerides essentially as they affect glucose, i.e. thiazides and beta-blockers clearly increase the level [24, 30-32], alpha-blockers clearly decrease it [30, 32-34], angiotensin-converting-enzyme inhibitors cause a slight decline $[24,30]$ and calcium-blocking agents have no clear effects [30]. The elevated triglyceride level is usually ascribed to increased synthesis although it is obvious that the catabolic rate also influences the level. Muscle endothelial lipoprotein lipase is decreased by $25-50 \%$ in obesity and Type 2 diabetes [35]. The fact that this enzyme is rate-limiting for triglyceride utilization does not mean that blood flow is not rate-limiting as well, rather the opposite. Only a few capillaries are perfused at rest with the number increasing proportionally as blood flow increases. More lipase is then brought into contact with the blood stream. Therefore, theoretically, muscle blood flow should be rate-limiting for the disposal of triglycerides.

\section{Vascular and rheologic changes in conditions with IR}

Long-term diabetes is associated with microangiopathy in many tissues, including skeletal muscles [36, 37]. Its main characteristic is thickening of the capillary basement membrane. The occurrence of microangiopathy is related to the aging process, hypertension, duration of diabetes and degree of metabolic control. In Type 2 diabetes the first signs may appear early in the history suggesting an in- dependent, possibly genetic, cause. Opinions differ as to how blood flow is influenced in the early stages of diabetes but there is good reason to assume that microangiopathy over a long period of time leads to microvascular failure and decreasing blood flow [38].

Erythrocytes from diabetic patients, both Type 1 (insulin-dependent) and Type 2, show poor rheologic properties. Higher pressure has to be applied for cells to pass narrow capillaries with the same velocity as cells from non-diabetic subjects. Deviation of up to $50 \%$ from the value for non-diabetic subjects has been reported [39]. Reduced deformability and increased aggregation tendency are considered to be the cause $[39,40]$ and several investigators have found these changes to correlate with the metabolic control. Similar rheologic changes have been demonstrated in erythrocytes from diabetic mice, rats and rabbits and also in leucocytes from human diabetic patients.

Long-standing hypertension is accompanied by rarefaction of small blood vessels in various tissues, $40-50 \%$ in skeletal muscles [40], and similar changes have been noted in animal models of hypertension [41-43]. Moreover, capillary density correlates with the percentage of oxidative fibres in the muscles [44] and both these variables correlate with insulin resistance, blood pressure and degree of obesity [44-47] (Fig. 2). Though it is largely unknown the extent to which all these relationships are independent, this hub of related physiological quantities probably reflect fundamental mechanisms behind the insulin resistance syndrome. Together with diabetic microangiopathy and rheologic cell changes they might provide the basis for the proposed role of muscle blood flow in IR.

\section{Conclusion}

Insulin resistance and Type 2 diabetes are accompanied by a progressive deterioration of the microcirculation in many tissues. The mechanism behind this association is obscure but currently accepted data may be arranged to fit a pathogenic model with vascular and circulatory changes causing a decline of muscle blood flow that finally leads to the metabolic disorder.

\section{References}

1. Ganrot PO, Curman B, Kroon B (1987) Type 2 diabetes. Primary vascular disorder with metabolic symptoms? Med Hypotheses 24: 77-86

2. Modan M, Halkin H, Almog S et al. (1985) Hyperinsulinemia. A link between hypertension obesity and glucose intolerance. J Clin Invest 75: 809-817

3. Reaven GM (1988) Role of insulin resistance in human disease. Diabetes 37: 1595-1607

4. DeFronzo RA, Ferrannini E (1991) Insulin resistance. A multifaceted syndrome responsible for NIDDM, obesity, hypertension, dyslipidemia, and atherosclerotic cardiovascular disease. Diabetes Care 14: 173-194

5. Holloszy JO, Constable SH, Young DA (1986) Activation of glucose transport in muscle by exercise. Diabetes Metab Rev 1: 409423

6. DeFronzo RA, Gunnarsson R, Björkman O, Olsson M, Wahren $\mathrm{J}$ (1985) Effects of insulin on peripheral and splanchnic glucose 
metabolism in noninsulin-dependent (type II) diabetes mellitus. J Clin Invest 76: 149-155

7. Baron AD, Brechtel G, Wallace P, Edelman SV (1988) Rates and tissue sites of non-insulin- and insulin-mediated glucose uptake in humans. Am J Physiol 255: E769-E774

8. Yki-Järvinen H, Young AA, Lamkin C, Foley JE (1987) Kinetics of glucose disposal in whole body and across the forearm in man. J Clin Invest 79: 1713-1719

9. Laakso M, Edelman SV, Olefsky JM, Brechtel G, Wallace P, Baron AD (1990) Kinetics of in vivo muscle insulin-mediated glucose uptake in human obesity. Diabetes 39: 965-974

10. Schultz TA, Lewis SB, Westbie DK, Wallin JD, Gerich JE (1977) Glucose delivery: a modulator of glucose uptake in contracting skeletal muscle. Am J Physiol 233: E514-E518

11. James DE, Burleigh KM, Storlien LH, Bennett SP, Kraegen EW (1986) Heterogeneity of insulin action in muscle: influence of blood flow. Am J Physiol 251: E422-E430

12. Grubb B, Snarr JF (1977) Effect of flow rate and glucose concentration on glucose uptake rate by the rat limb. Proc Soc Exp Biol Med 154:33-36

13. DeFronzo RA, Ferrannini E, Sato Y, Felig P, Wahren J (1981) Synergistic interaction between exercise and insulin on peripheral glucose uptake. J Clin Invest 68: 1468-1474

14. Jacquez JA (1984) Red blood cell as a glucose carrier: significance for placental and cerebral glucose transfer. Am J Physiol 246: R289-R298

15. Hudlická O (1985) Regulation of muscle blood flow. Clin Physiol 5:201-229

16. Laakso M, Edelman SV, Brechtel G, Baron AD (1990) Decreased effect of insulin to stimulate skeletal muscle blood flow in obese man. A novel mechanism for insulin resistance. J Clin Invest 85: 1844-1852

17. Katz MA, Janjan N (1978) Forearm hemodynamics and responses to exercise in middle-aged adult-onset diabetic patients. Diabetes 27: 726-731

18. Menon RK, Grace AA, Burgoyne W, Fonseca VA, James IM, Dandona $\mathbf{P}$ (1992) Muscle blood flow in diabetes mellitus. Evidence of abnormality after exercise. Diabetes Care 15: 693-695

19. McVeigh GE, Brennan GM, Johnston GD et al. (1992) Impaired endothelium-dependent and independent vasodilation in patients with type 2 (non-insulin-dependent) diabetes mellitus. Diabetologia 35: $771-776$

20. Baron AD, Laakso M, Brechtel G, Edelman SV (1991) Reduced capacity and affinity of skeletal muscle for insulin-mediated glucose uptake in non-insulin-dependent diabetic subjects. Effects of insulin therapy. J Clin Invest 87: 1186-1194

21. Laakso M, Edelman SV, Brechtel G, Baron AD (1992) Impaired insulin-mediated skeletal muscle blood flow in patients with NIDDM. Diabetes 41: 1076-1083

22. Julius S, Gudbrandsson T, Jamerson K, Shahab ST, Andersson O (1991) The hemodynamic link between insulin resistance and hypertension. J Hypertens 9: 983-986

23. Pollare T, Lithell H, Selinus I, Berne C (1989) Sensitivity to insulin during treatment with atenolol and metoprolol: a randomised, double blind study of effects on carbohydrate and lipoprotein metabolism in hypertensive patients. BMJ 298: 11521157

24. Pollare T, Lithell H, Berne C (1989) A comparison of the effects of hydrochlorothiazide and captopril on glucose and lipid metabolism in patients with hypertension. $\mathrm{N}$ Engl $\mathrm{J}$ Med 321: 868-873

25. Lithell H, Pollare T, Berne C, Saltin B (1992) The metabolic and circulatory response to beta-blockade in hypertensive men is correlated to muscle capillary density. Blood Pressure 1: 20-26

26. Pollare T, Lithell H, Selinus I, Berne C (1988) Application of prazosin is associated with an increase of insulin sensitivity in obese patients with hypertension. Diabetologia 31: 415-420
27. Kodama J, Katayama S, Tanaka K, Itabashi A, Kawazu S, Ishii J (1990) Effect of captopril on glucose concentration. Possible role of augmented postprandial forearm blood flow. Diabetes Care 13: $1109-1111$

28. Pollare T, Lithell H, Mörlin C, Präntare H, Hvarfner A, Ljunghall S (1989) Metabolic effects on diltiazem and atenolol: results from a randomized, double blind study with parallel groups. J Hypertens 7: 551-559

29. Ferrannini $\mathrm{E}$ (1992) Insulin and blood pressure: possible role of hemodynamics. Clin Exp Hypertens [A] 14: 271-284

30. Kesäniemi YA, Lilja M (1991) Hypertension, plasma lipids and antihypertensive drugs. Ann Med 23: 347-351

31. Ames RP (1991) Hyperlipidemia in hypertension: causes and prevention. Am Heart J 122: 19-24

32. Leren P, Foss PO, Helgland A, Hjermann I, Holme I, Lund-Larsen PG (1980) Effect of propranolol and prazosin on blood lipids. The Oslo study. Lancet II: $4-6$

33. Lowenstein J, Neusy A-J (1984) Effect of prazosin and propranolol on serum lipids in patients with hypertension. Am J Med 76: 79-84

34. Deger $G$ (1986) Effect of terazosin on serum lipids. Am J Med 80 [Suppl 5B]: 82-85

35. Pollare T, Vessby B, Lithell H (1991) Lipoprotein lipase activity in skeletal muscle is related to insulin sensitivity. Arterioscler Thromb 11: 1192-1203

36. Siperstein MD, Unger RH, Madison LL (1968) Studies of muscle capillary basement membranes in normal subjects, diabetic, and prediabetic patients. J Clin Invest 47: 1973-1999

37. Kilo C, Vogler N, Williamson JR (1972) Muscle capillary basement membrane changes related to aging and to diabetes mellitus. Diabetes 21: 881-905

38. Tooke JE (1989) Microcirculation and diabetes. Br Med Bull 45: 206-223

39. McMillan DE, Utterback NG, La Puma J (1978) Reduced erythrocyte deformability in diabetes. Diabetes 27: 895-901

40. Schmid-Schönbein H, Volger E (1976) Red-cell aggregation and red-cell deformability in diabetes. Diabetes 25 [Suppl 2]:897-902

41. Greene AS, Tonellato PJ, Lui J, Lombard JH, Cowley AW Jr (1989) Microvascular rarefaction and tissue vascular resistance in hypertension. Am J Physiol 256: H126-H131

42. Hansen-Smith F, Greene AS, Cowley AW Jr, Lombard JH (1990) Structural changes during microvascular rarefaction in chronic hypertension. Hypertens 15: 922-928

43. Bohlen HG (1989) The microcirculation in hypertension. J Hypertens 7 [Suppl 7]: S117-S124

44. Lillioja S, Young AA, Culter CL et al. (1987) Skeletal muscle capillary density and fiber type are possible determinants of in vivo insulin resistance in man. J Clin Invest 80: 415-424

45. Lithell H, Lindgärde $F$, Hellsing $\mathrm{K}$ et al. (1981) Body weight, skeletal muscle morphology, and enzyme activities in relation to fasting serum insulin concentration and glucose tolerance in 48 year-old men. Diabetes 30: 19-25

46. Juhlin-Dannfelt A, Frisk-Holmberg M, Karlsson J, Tesch P (1979) Central and peripheral circulation in relation to musclefiber composition in normo- and hypertensive man. Clin Sci 56: 335-340

47. Wade AJ, Marbut MM, Round JM (1990) Muscle fibre type and aetiology of obesity. Lancet 335: 805-808

Dr.P.O.Ganrot

Department of Clinical Chemistry

Örebro Medical Center Hospital

S-701 85 Örebro

Sweden 